\title{
The Mechanism of Liberation of Penicillinase from Bacillus subtilis
}

\author{
By M. R. POLLOCK \\ National Institute for Medical Research, The Ridgeway, Mill Hill, London, N.W. 7
}

(Received 13 March 1961)

\section{SUMMARY}

The effects of various factors on the release of penicillinase from apparently undamaged cells of a growing culture of Bacillus subtilis were investigated. The enzyme was not eluted from the cells by treating them with high concentrations of salt. Its liberation did not take place at all at $0^{\circ}$, and was nearly completely inhibited at $\mathrm{pH}$ values below $\mathbf{6} \cdot \mathbf{0}$, whereas chloramphenicol, at concentrations sufficient to cause complete cessation of growth, caused only partial inhibition of enzyme release. The penicillinase-releasing action of extracts containing heat-labile 'autolytic' factors from older cells of the same organism could not be dissociated from their damaging effect on the cell, as indicated by concomitant release of the normally intracellular $\alpha$-glucosidase. It is concluded that normal penicillinase liberation is controlled by enzymic reactions, as yet unidentified, involving detachment of the enzyme from structures superficially located in the cell envelope.

\section{INTRODUCTION}

In the first two papers of this series some evidence was presented to suggest that the liberation of penicillinase from a growing culture of Bacillus subtilis 6346 may involve a release of the enzyme from the superficial layers of apparently intact cells. The present paper records the results of a direct investigation of the liberation process itself, with a view to characterizing it and obtaining further information on its nature. Minor degrees of cell damage, insufficient to cause measurable lysis, were detected by following the leakage into the medium of an 'intracellular' $\alpha$-glucosidase whose synthesis was induced in the cells, during the period when penicillinase was being formed, by the addition of a small quantity of maltose (Pollock, 1961 b).

'Normal' or 'physiological' penicillinase liberation is defined here as the penicillinase release which occurs in untreated cultures in the absence of cell damage sufficient to cause leakage of $\alpha$-glucosidase greater than the irreducible minimum of up to $5 \%$ that was always liable to take place. On this criterion, the conditions under investigation in many experiments caused significant cell damage, and in such cases it could oniy be concluded that the associated increase in penicillinase liberation, which nearly always occurred, was 'unphysiological'. Unfortunately this took place all too frequently, and in most of the other experiments the factors being studied had no detectable effect. Our conclusions have therefore been limited, extending only to an indication that 'normal' penicillinase liberation is not a matter only of physico-chemical factors, but involves more complicated processes having an enzymic basis. 


\section{METHODS}

The strain (6346) of Bacillus subtilis used, the techniques employed, the definitions adopted and the general approach to the problem have been described and discussed previously (Pollock 1961b). It should be particularly noted that the standard 'zero' reference time $(0 \mathrm{hr}$.) from which all time periods are measured was taken as the point when the population density of growing cultures reached the equivalent of $0.1 \mathrm{mg}$. bacterial dry $\mathrm{wt} . / \mathrm{ml}$. Unless stated otherwise this has also been the time when cells were induced to form penicillinase and $\alpha$-glucosidase.

\section{RESULTS}

\section{Effect of $p H$ value}

When the casein hydrolysate (CH) medium was supplemented with $2 \%(\mathrm{w} / \mathrm{v})$ glucose, the organisms were found never to release more than a small fraction of their total penicillinase. Even after $6 \mathrm{hr}$. such glucose-grown organisms had liberated only $15 \%$ of their total penicillinase, in contrast to organisms grown in $\mathrm{CH}$ medium without glucose, where $40 \%$ or more of the enzyme was released into medium during the same period (see Pollock, $1961 b$ ). This effect was finally shown to be due mainly, if not entirely, to the lower $\mathrm{pH}$ value of the culture, which usually fell from $7 \cdot 0$ to $5 \cdot 0-5 \cdot 5$ in glucose-containing cultures.

It was confirmed that the low amounts of extracellular penicillinase were not due to selective inactivation of exo-enzyme under the conditions associated with glucosegrown cultures. Concentrated dialysed supernatant fluid from a penicillin-induced culture at a final concentration of 13.5 units penicillinase $/ \mathrm{ml}$. was added to a $3 \mathrm{hr}$. uninduced culture of Bacillus subtilis growing in $\mathrm{CH}$ medium $+2 \%(\mathrm{w} / \mathrm{v})$ glucose. Incubation continued for a further $2 \mathrm{hr}$. caused no significant loss of activity.

In the experiment summarized in Table 1 a culture grown in $\mathrm{CH}$ medium $+2 \%$ $(\mathrm{w} / \mathrm{v})$ glucose was split into two portions at $3 \mathrm{hr}$., and both portions incubated in large tubes at $35^{\circ}$, aerated by a flow of air through a sparger at $500 \mathrm{ml} . / \mathrm{min}$. In one portion the $\mathrm{pH}$ value was adjusted to $\mathrm{pH} \mathbf{7 \cdot 8}$ and kept constant thereafter for the $2 \mathrm{hr}$. of the experiment by an automatic titrator (Radiometer, Titrator TTTI, V. A. Howe and Co. Ltd., 46 Pembridge Road, W. 11) delivering minute quantities of $\mathrm{N}-\mathrm{NaOH}$ into the culture continuously under the control of a $\mathrm{pH}$ meter. The total volume of $\mathrm{NaOH}$ thus added never increased the volume of the cultures by more than $3.5 \%$ and was ignored in comparing the results. A complementary experiment was also done without glucose in the medium, one of the two sister cultures being kept at $\mathrm{pH} 5 \cdot 2$ by automatic delivery of $\mathrm{N}-\mathrm{HCl}$ while the control culture was left to drift towards alkalinity without adjustment. It can be seen that several times less enzyme was liberated in cultures at the lower $\mathrm{pH}$ values, regardless of whether or not glucose was present.

\section{Effect of chloramphenicol}

Addition of $40 \mu \mathrm{g}$. chloramphenicol $/ \mathrm{ml}$. to a culture of Bacillus subtilis 6346 inhibited growth (opacity increase) and penicillinase production almost completely. The effect on enzyme liberation appeared at first to be variable. To obtain higher enzyme titres and more reliable results, some cultures were induced with cephalosporin $\mathrm{C}(1 \mu \mathrm{g} . / \mathrm{ml}$.) and it was at once clear that significant enzyme release occurred 
Table 1. Effect of $p H$ value on the liberation of penicillinase from penicillininduced Bacillus subtilis 6346 growing in $\mathrm{CH}$ medium

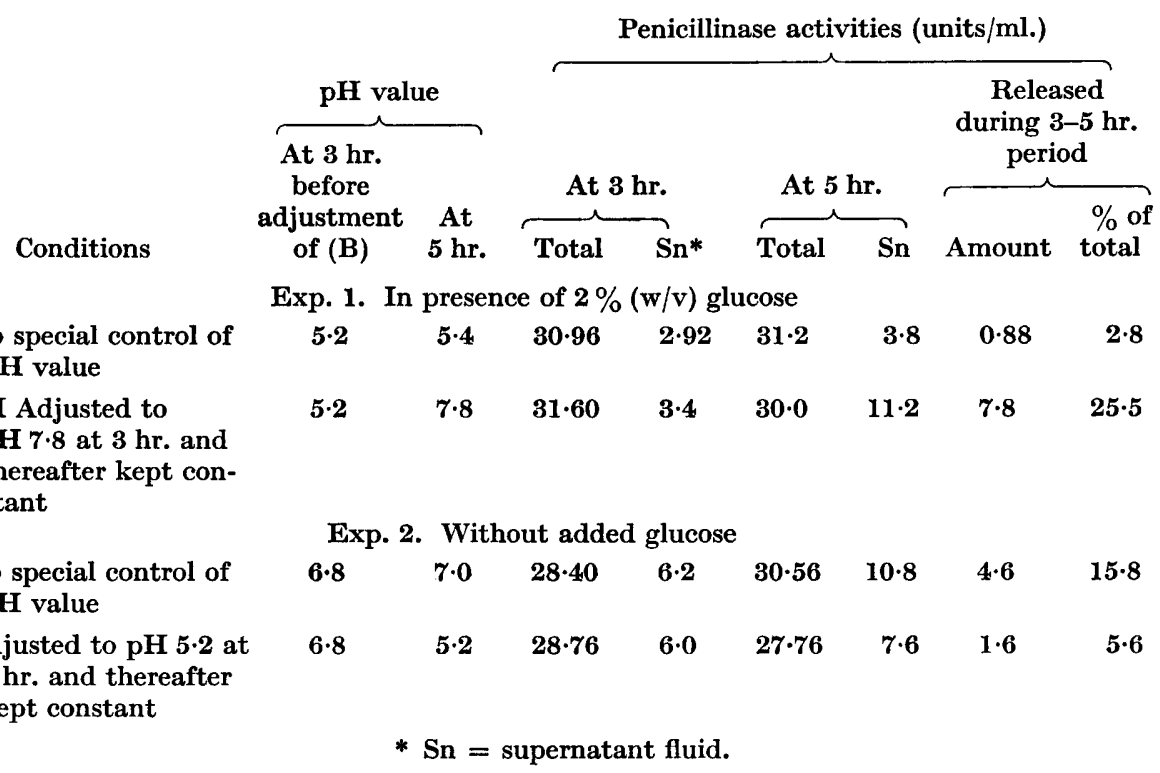

in the presence of chloramphenicol; but no quantitative comparison with untreated cultures was possible because the total enzyme production was so much less than in the control. Repeated experiments with benzylpenicillin-induced cultures finally showed that chloramphenicol did in fact cause a significant and consistent inhibition of liberation of $\mathbf{3 0 - 5 0 \%}$; even in cultures where the slight difference in $\mathrm{pH}$ value from the control (due to growth inhibition and subsequently decreased metabolic drift towards alkalinity that is always shown by $B$. subtilis when growing in $\mathbf{C H}$ medium) was obliterated by the automatically titrating $\mathrm{pH}$ regulator, adjusted so that the $\mathrm{pH}$ value of the control culture was kept identical with that of the chloramphenicol-treated culture (measured independently with a second $\mathrm{pH}$ meter), as shown in Table 2. Neither earlier addition of chloramphenicol (namely at $2 \mathrm{hr}$.

Table 2. Effect of chloramphenicol on the liberation of penicillinase from penicillin-induced Bacillus subtilis 6346 in $\mathrm{CH}$ medium

\begin{tabular}{|c|c|c|c|c|c|c|c|c|}
\hline \multirow[b]{4}{*}{ Conditions } & & & \multicolumn{6}{|c|}{ Penicillinase activities (units/ml.) } \\
\hline & \multicolumn{2}{|c|}{ pH } & \multirow{2}{*}{\multicolumn{2}{|c|}{ At $3 \mathrm{hr}$. }} & \multirow{2}{*}{\multicolumn{2}{|c|}{ At $5 \mathrm{hr}$. }} & \multicolumn{2}{|c|}{$\begin{array}{l}\text { Released into } \\
\text { medium during } \\
3-5 \mathrm{hr} \text {. period }\end{array}$} \\
\hline & & & & & & & & \\
\hline & $3 \mathrm{hr}$. & $5 \mathrm{hr}$. & Total & Sn* & Total & Sn & Amount & total \\
\hline Control (no addition) & $7 \cdot 0$ & $7 \cdot 65$ & $17 \cdot 6$ & $3 \cdot 6$ & $21 \cdot 2$ & $6 \cdot 8$ & $\mathbf{3 \cdot 2}$ & 15 \\
\hline $\begin{array}{l}\text { Chloramphenicol } 40 \mu \mathrm{g} . / \mathrm{ml} \text {. } \\
\text { added at } 3 \mathrm{hr} \text {. }\end{array}$ & $7 \cdot 0$ & $7 \cdot 65$ & - & - & $20 \cdot 4$ & $\mathbf{5 \cdot 2}$ & $\mathbf{1 \cdot 6}$ & $7 \cdot 8$ \\
\hline
\end{tabular}


instead of $3 \mathrm{hr}$.) nor raising its concentration to $100 \mu \mathrm{g} . / \mathrm{ml}$. caused any significant change in the proportion of enzyme released.

\section{Effect of temperature}

Figure 1 shows the effect of temperature on penicillinase release from a culture previously induced with $0.25 \mathrm{mg}$. maltose $/ \mathrm{ml}$. and cephalosporin $\mathrm{C}(1 \mu \mathrm{g} . / \mathrm{ml}$.) treated with chloramphenicol $(40 \mu \mathrm{g} . / \mathrm{ml}$.) at $3 \mathrm{hr}$. and immediately distributed in three lots in water baths maintained at $0^{\circ}, 21^{\circ}$ and $35^{\circ}$, respectively. The proportions of $\alpha$-glucosidase released after $2 \frac{1}{2} \mathrm{hr}$. incubation at these three temperatures were found to be $36 \cdot 3,4 \cdot 1$ and $5 \cdot 6 \%$, respectively. The cold treatment obviously

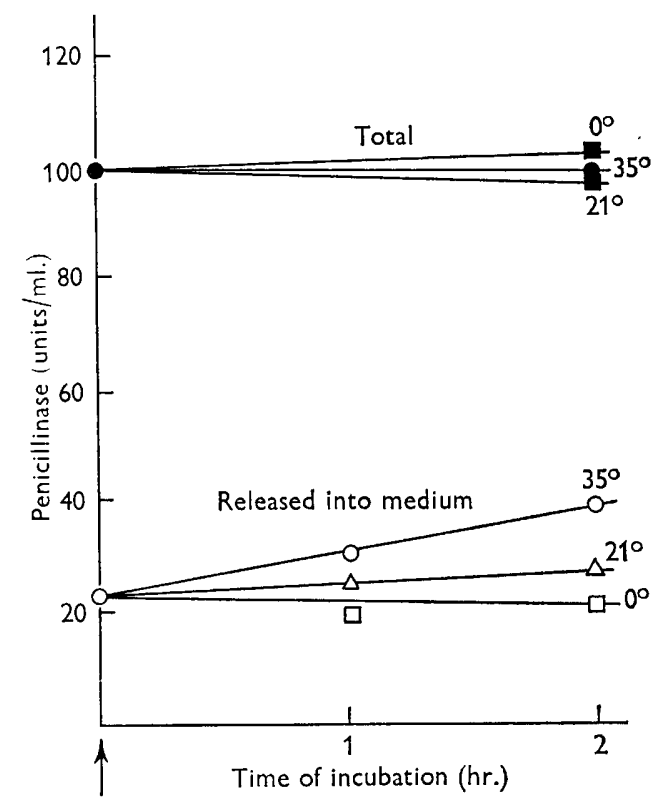

Fig. 1. The effect of temperature on the liberation in the presence of chloramphenicol of penicillinase from 3-hr. cells of Bacillus subtilis 6346 , previously grown at $35^{\circ}$ after induction with cephalosporin $\mathrm{C}\left(10 \mu \mathrm{g} \cdot / \mathrm{ml}\right.$.). $35^{\circ}$ (circles:, 0$) ; 21^{\circ}$ (triangles: $\left.\Delta, \triangle\right) ; 0^{\circ}$ (squares : $\square, \square$ ); enzyme released into medium (open symbols : $O, \Delta, \square$ ); total enzyme (filled-in symbols : $\mathbf{O}, \boldsymbol{\Delta}, \mathbf{\square}$ ). Arrow indicates point of addition of chloramphenicol $40 \mu \mathrm{g} \cdot / \mathrm{ml}$.

caused considerable cell damage, without, however, leading to penicillinase liberation, as long as the temperature was kept at $0^{\circ}$. When, however, the culture was returned to $35^{\circ}$, even brief cold treatment (e.g. $5 \mathrm{~min}$. at $0^{\circ}$ ) resulted in substantial subsequent 'damage-release' of penicillinase, as shown in the first paper in this series (Pollock, $1961 b$; Fig. 5). In another experiment it was found that the penicillinase liberation increased further with temperatures above $35^{\circ}$; but at $45^{\circ}$ this was always associated with considerable cell damage and could not therefore be regarded as physiological.

The rather striking dissociation between release of $\alpha$-glucosidase and penicillinase at $0^{\circ}$ in the experiment illustrated in Fig. 1 supports the original conclusion (Kushner \& Pollock, 1961) that cell-bound penicillinase is normally fixed to particulate cell structure and does not exist 'free' in the cytoplasm (as appears to be the case with 
$\alpha$-glucosidase), and shows further that both the normal 'physiological' mechanism for the release of penicillinase and the secondary 'artefactual' release process, which under all other conditions so far investigated comes into effect following cell damage, are inoperative at $0^{\circ}$ and therefore more likely to be dependent on some enzymic process in the cell rather than on diffusion or other purely physico-chemical factors.

Table 3. Failure of high concentrations of salts to elute penicillinase from penicillin-induced Bacillus subtilis 6346 after $2 \mathrm{hr}$. treatment at $0^{\circ}$

\begin{tabular}{|c|c|c|c|c|c|c|}
\hline \multirow[b]{2}{*}{ Treatment } & \multicolumn{3}{|c|}{$\begin{array}{c}\alpha \text {-Glucosidase } \\
\text { (as } \mathrm{m} \mu \mathrm{mole} p \text {-nitrophenol } / \mathrm{ml} . / \mathrm{hr} \text {.) }\end{array}$} & \multicolumn{3}{|c|}{$\begin{array}{l}\text { Penicillinase } \\
\text { (units/ml.) }\end{array}$} \\
\hline & Total & In $\mathrm{Sn}$ & $\%$ in $\mathrm{Sn}^{*}$ & Total & In Sn & $\%$ in $\mathbf{S n}$ \\
\hline \multicolumn{7}{|c|}{ Potassium phosphate $(\mathrm{pH} 7 \cdot 0)$} \\
\hline $10^{-3} \mathrm{M}$ & 3130 & 2030 & 65 & $17 \cdot 0$ & 0.48 & $2 \cdot 8$ \\
\hline $5 \times 10^{-2} M$ & $\mathbf{3 1 3 0}$ & 2500 & 80 & $17 \cdot 8$ & $0 \cdot 68$ & $3 \cdot 8$ \\
\hline $2 \times 10^{-1} M$ & 3130 & 2500 & 80 & $16 \cdot 1$ & $0 \cdot 76$ & $4 \cdot 7$ \\
\hline \multicolumn{7}{|c|}{ Ammonium sulphate $(\mathrm{pH} 7 \cdot 0)$} \\
\hline $5 \times 10^{-2} M$ & $\mathbf{3 1 3 0}$ & 2630 & 84 & $16 \cdot 6$ & $0 \cdot 56$ & $3 \cdot 4$ \\
\hline $2 \times 10^{-1} M$ & 2970 & 2630 & 89 & $17 \cdot 0$ & $1 \cdot 12$ & $6 \cdot 6$ \\
\hline
\end{tabular}

\section{Effect of high salt concentrations}

A $3 \mathrm{hr}$. culture of Bacillus subtilis 6346, previously induced with penicillin and maltose, was cooled to $0^{\circ}$ and the organism resuspended in solutions of potassium phosphate and ammonium sulphate $(\mathrm{pH} \mathrm{7.0})$ at concentrations of up to $0.2 \mathrm{M}$ for $2 \mathrm{hr}$. (at $0^{\circ}$, instead of $35^{\circ}$, to avoid 'damage-release'). Table 3 shows that negligible quantities of penicillinase $(\ngtr 7 \%$ ) were released by this treatment, which would be expected to elute a substantial fraction of enzyme, were the normal liberation process due to a desorption of protein bound to the cell by simple ionic linkages. This experiment shows the profound cell damage that occurred as a result of this treatment which led to the release of up to $90 \%$ of the $\alpha$-glucosidase. It is also a further indication of the different manner in which the penicillinase is bound to the cells of $B$. subtilis as compared with $B$. cereus, where analogous salt treatment eluted nearly all the cell-bound $\beta$-penicillinase within a few minutes (Pollock \& Kramer, 1958).

\section{Possible role of enzymes}

Effect of enzyme inhibitors. With $3 \mathrm{hr}$.-cultures of Bacillus subtilis 6346 growing in $\mathrm{CH}$ medium many of the substances and factors tested $\left(1.6 \times 10^{-3} \mathrm{M}-p\right.$-chloromercuribenzoate; $0 \cdot 05-1 \cdot 0 \%(\mathrm{w} / \mathrm{v})$ sodium deoxycholate; $8.3 \times 10^{-4} \mathrm{M}-8$-hydroxyquinoline) increased penicillinase liberation but rapidly led to cell damage ( $\alpha$-glucosidase leak) so that their action on physiological release could not be assessed. Other substances added ( $5 \times 10^{-3} \mathrm{M}^{-\mathrm{NaN}_{3}} ; 10^{-3} \mathrm{M}-2$ :4-dinitrophenol; $\mathrm{CuSO}_{4}, 100 \mu \mathrm{g} . / \mathrm{ml}$. ; $0.02 \mathrm{M}$ sodium succinate; mercaptoethanol, $0.5 \mathrm{mg} . / \mathrm{ml}$; carbamylcholine, $0.1 \mathrm{mg} . / \mathrm{ml}$.; histamine phosphate, $0 \cdot 1 \mathrm{mg} . / \mathrm{ml}$.) had no detectable effect. Ethylenediamine tetra-acetic acid $\left(10^{-3} \mathrm{M}\right)$, in the presence of chloramphenicol $(40 \mu \mathrm{g} / \mathrm{ml}$.), had a slight inhibitory effect on penicillinase liberation (up to $40 \%$ from cells of a cephalosporin C-induced culture in some experiments), but this was not consistently repeatable. A similar 
variable but even slighter inhibitory effect was shown by low doses of ultraviolet radiation in the absence of chloramphenicol. High concentrations of $\mathrm{Mg}^{++}(0 \cdot 05 \mathrm{M}$ $\mathrm{MgSO}_{4}$ ) which had been shown to have a very striking inhibitory effect on the release of the enzyme from membrane preparations or damaged cell suspensions (Kushner \& Pollock, 1961) had no action whatever in cultures growing normally in CH medium.

Proteinases. The specific penicillinase-liberating action of proteinases on sucrosetreated suspensions of Bacillus subtilis 6346 (Kushner \& Pollock, 1961) and the possibly enzymic nature of the liberation process suggested that this might normally involve the action of some proteolytic enzyme or esterase, either by direct detachment of the enzyme by hydrolysis of a peptide bond which linked it to some surface structure, or by destruction (solubilization) of a protein responsible for its fixation. Attempts to inhibit the hypothetical esterase involved, by addition of diisopropylfluorophosphate (DFP) and heparin $(0 \cdot 1 \%)$ were unsuccessful. Concentrations of DFP up to a nearly saturated solution (addition of 1 drop of pure DFP in $10 \mathrm{ml}$. of culture, repeated twice during the $2 \mathrm{hr}$. experiment) had no significant effect on liberation of penicillinase from cephalosporin $\mathrm{C}$-induced cells of a culture previously treated with chloramphenicol $(40 \mu \mathrm{g} . / \mathrm{ml}$.$) .$

Table 4. The effect of crude dialysed extracts of organisms from old Bacillus subtilis 6346 cultures on release of $\alpha$-glucosidase and penicillinase from cells of a maltoseand penicillin-induced homologous $\mathrm{B}$. subtilis culture in casein hydrolysate $(\mathrm{CH})$ medium

\begin{tabular}{|c|c|c|c|c|c|c|c|c|}
\hline \multirow[b]{2}{*}{ Time } & \multirow{2}{*}{$\begin{array}{c}\text { Volume } \\
\text { (ml.) of } \\
\text { extract* } \\
\text { added } \\
\text { (at } 3 \mathrm{hr} . \text { ) } \\
\text { to } 10 \mathrm{ml} . \\
\text { culture }\end{array}$} & \multirow{2}{*}{$\begin{array}{c}\text { Bacterial } \\
\text { suspension } \\
\text { concentration } \\
\text { (equiv. mg. } \\
\text { dry } \\
\text { wt./ml.) }\end{array}$} & \multicolumn{3}{|c|}{$\begin{array}{c}\alpha \text {-Glucosidase } \\
\text { (m } \mu \text { mole } p \text {-nitrophenol/ } \\
\text { ml./hr.) }\end{array}$} & \multicolumn{3}{|c|}{$\begin{array}{l}\text { Penicillinase } \\
\text { units/ml.) }\end{array}$} \\
\hline & & & Total & $\underset{\text { Sn } \dagger}{\text { In }}$ & $\begin{array}{l}\% \\
\text { in Sn }\end{array}$ & Total & $\begin{array}{l}\text { In } \\
\text { Sn }\end{array}$ & $\begin{array}{c}\% \\
\text { in Sn }\end{array}$ \\
\hline $\begin{array}{l}3 \mathrm{hr} \text {. (before } \\
\text { addition of } \\
\text { extract) }\end{array}$ & - & 0.85 & 4310 & 47 & $1 \cdot 1$ & $21 \cdot 6$ & $4 \cdot 8$ & $22 \cdot 2$ \\
\hline \multirow{6}{*}{$5 \frac{1}{2} \mathrm{hr} .\{$} & o & $2 \cdot 10$ & 4130 & 65 & $1 \cdot 6$ & $20 \cdot 8$ & $7 \cdot 6$ & $36 \cdot 5$ \\
\hline & 0.023 & $2 \cdot 25$ & 4000 & 108 & $2 \cdot 7$ & $21 \cdot 6$ & $8 \cdot 3$ & $38 \cdot 5$ \\
\hline & 0.067 & $2 \cdot 44$ & 4500 & 338 & $7 \cdot 5$ & $21 \cdot 2$ & $9 \cdot 5$ & 44.8 \\
\hline & 0.2 & $2 \cdot 10$ & 4810 & 1275 & $26 \cdot 5$ & $22 \cdot 0$ & $12 \cdot 2$ & $55 \cdot 3$ \\
\hline & 0.5 & 1.04 & 4900 & 3090 & 63 & $20 \cdot 4$ & $15 \cdot 6$ & 76.5 \\
\hline & 1.8 & 0.37 & 5100 & 4560 & 89.5 & $21 \cdot 6$ & $13 \cdot 3$ & $61 \cdot 7$ \\
\hline
\end{tabular}

* The extract was diluted so that $1.0 \mathrm{ml}$. contained material originally derived from the organisms of $10 \mathrm{ml}$. of a $24 \mathrm{hr}$. culture. Further details, see text.

$\dagger$ Sn $=$ supernatant fluid.

Crude cell extracts. Extracts were prepared from organisms of an uninduced culture of Bacillus subtilis 6346 , by resuspending the organisms at ten times their original concentration in $10^{-2} \mathrm{M}$-potassium phosphate buffer $(\mathrm{pH} 7 \cdot 0)$ and crushing them in a Hughes press at $-30^{\circ}$. The supernatant fluid after centrifugation of the disrupted suspension at $20,000 \mathrm{~g}$ for $20 \mathrm{~min}$. was dialysed against $10^{-3} \mathrm{M}$-potassium phosphate $(\mathrm{pH} 7 \cdot 0)$ and concentrated by freeze-drying. These extracts had enzyme-like properties which appeared to be similar to those of the 'autolysin' of $\boldsymbol{B}$. subtilis strain $\mathbf{H}$ described by Nomura \& Hosoda (1956). When added to cultures of Bacillus subtilis 6346 in $\mathrm{CH}$ medium the extracts consistently caused cell damage, the extent of 
which depended upon the quantity of extract and the age of the culture from which it was prepared. Severe damage resulted in cell lysis. Less severe damage was shown by leakage of $\alpha$-glucosidase and increase in penicillinase liberation; but it was not possible to dissociate these two effects by diluting the extract. A typical experiment is illustrated in Table 4 where increasing quantities of an extract prepared from a $24 \mathrm{hr}$. culture were added to $10 \mathrm{ml}$. samples of a $3 \mathrm{hr}$.-culture previously induced with maltose and penicillin. The effects on opacity increase and release of the two induced enzymes into the medium were followed during incubation for a further $2 \frac{1}{2} \mathrm{hr}$. It can be seen : (a) only the highest concentration of extract caused obvious cell lysis (decrease in suspension opacity) although $1 / 27$ of this concentration caused a significant $\alpha$-glucosidase leak of $7.5 \% ;(b)$ liberation of penicillinase was increased by addition of extract very roughly in proportion to the extent of $\alpha$-glucosidase release; there was no concentration of extract which stimulated penicillinase release without significantly increasing the release of $\alpha$-glucosidase above the basal value of $\mathbf{1 . 6} \%$ shown by the control culture. Extracts from the organisms of young cultures were very much less active in causing cell damage than extracts from organisms of older cultures. For instance, the degree of cell damage, as measured by $\% \alpha$-glucosidase leakage, produced by extract of a given dry weight from organisms of $3 \mathrm{hr}$.or $6 \mathrm{hr}$-cultures, could be evoked by approximately one-fiftieth of that quantity of extract prepared from $20 \mathrm{hr}$.-cultures. The autolytic factor or factors concerned were completely inactivated by boiling for $30 \mathrm{~min}$. It is clear that the factor(s) was being produced in quantity only in old cultures, where some slight activity was also demonstrable in concentrated dialysed supernatant fluid as well as in the organisms themselves.

In addition, extracts of organisms from 20 to $24 \mathrm{hr}$. cultures were found to contain proteinase activity, whose action in liquefying gelatin and destroying $\alpha$-glucosidase was almost completely inhibited by $5 \times 10^{-3} \mathrm{M}-\mathrm{DFP}$. For this reason this proteinase activity can be almost certainly rejected as participating in normal penicillinase liberation or in the 'damage-release' effect of the cell extracts described above, because these processes are not affected by DFP. It is possible that some sort of lysozyme-like enzyme, known to be formed by certain strains of Bacillus subtilis (Richmond, 1959a, b) might be partly responsible for the lytic action of these extracts; but it is rather unlikely on a priori grounds that such an enzyme plays a part in normal penicillinase liberation. In any case, egg-white lysozyme by itself had a completely different action: at concentrations of $1 \mu \mathrm{g} . / \mathrm{ml}$. and above, it caused rapid lysis of $3-\mathrm{hr}$. cultures, whereas at $0 \cdot 4 \mu \mathrm{g} . / \mathrm{ml}$. and below there was no detectable effect whatever (no growth inhibition, no leak of $\alpha$-glucosidase, no stimulation of penicillinase liberation). All further attempts, by graded ammonium sulphate precipitation, zone electrophoresis and column fractionation, to isolate a specific penicillinase-liberating factor from these extracts, by separation from other material which might be interfering with its action or causing cell damage, have so far failed.

\section{DISCUSSION}

The problem of exo-enzyme liberation from bacteria has been approached in the absence of any real knowledge about the nature of the structural barriers or physical or chemical entities which may obstruct free diffusion of penicillinase from a cell after the enzyme is formed. It may well be that Bacillus subtilis 6346 penicillinase 
is a special case and that the mechanism of its liberation is unrelated to the mechanism acting on other exo-enzymes (e.g. $\alpha$-amylase from the same strain) where little or no enzymic activity is found to be associated with the cell under any conditions (Dr R. A. Darrow; personal communication) and where, therefore, the liberation process may be linked with the formation of the enzymes (either de novo or from an enzymically inactive high molecular weight precursor).

The classical concept of the bacterial cell as consisting of cytoplasm surrounded by a selectively impermeable membrane enveloped by a relatively permeable cell wall (see Salton, 1960; McQuillen, 1960) rather implied that the essential process involved in enzyme release must be its passage through the cytoplasmic membrane. Such a picture may be mistaken. The cytoplasmic membrane has chemical and anatomical reality and there is good reason for believing it to be mainly responsible for the selective permeability of the bacterial cell. But little is known about how exo-enzymes are formed and nothing about the site of their synthesis. It is possible that the process of specific polypeptide chain production which leads to their formation occurs outside the main permeability barrier of the cell. In any case, the classical picture of a continuous and undifferentiated cytoplasmic membrane may be a gross oversimplification. In Bacillus subtilis itself there are now indications of a sort of rudimentary endoplasmic reticulum (Glauert, Brieger \& Allen, 1961) which might play a part in enzyme liberation. Finally, the barrier to large molecules offered by the cell wall is quite unknown, though Mitchell \& Moyle (1959) and Mitchell (1961) have produced evidence which suggests that in Staphylococcus aureus and Escherichia coli it may not be negligible.

The present work permits only tentative and limited conclusions; but they may be useful in forming a basis for further studies. Assuming that the population of organisms in the culture is homogeneous with respect to enzyme release it can be accepted that at least a fair proportion of the penicillinase originally bound to cells of Bacillus subtilis is released into the medium by a process not involving marked cell damage. The complete inhibition of liberation at $0^{\circ}$, the zero order kinetics, the partial inhibition by chloramphenicol and the failure to elute enzyme from the cells by high concentrations of salts, all suggest that the process may be enzymic rather than physico-chemical. Chloramphenicol would be expected to inhibit the formation but not the functioning of such an enzyme system and would therefore cause only partial inhibition of the processes governed by the enzyme; this was what was observed. But it must be admitted that the failure to increase the inhibition of enzyme release by adding chloramphenicol earlier on during cultivation, when the cell content of the hypothetical enzymes responsible for liberation might be expected to be lower, does not support this interpretation. Conclusive evidence about the nature of the enzyme or enzymes involved has not been obtained.

Cell extracts of organisms from old cultures of the homologous strain of Bacillus subtilis 6346 increased the rate of penicillinase release from organisms from $3-\mathrm{hr}$. cultures. The main question is, what part, if any, substances present in these extracts may play in normal physiological liberation of the enzyme. But this stimulatory effect on penicillinase release was always associated, pari passu, with cell damage, as indicated by a leakage of $\alpha$-glucosidase which did not occur in cultures which were spontaneously liberating penicillinase in the normal way. It did not prove possible, by a variety of techniques, to dissociate the two effects. Such 
'autolytic' extracts might be expected to contain many different enzymes; but the only activity present which was specifically identified was that of a DFP-sensitive proteinase. This could be rejected as a possible agent for normal penicillinase liberation because of the latter's insusceptibility to inhibition by DFP. This negative finding does not completely exclude the possibility that a proteinase of some sort plays a part in penicillinase liberation, since DFP-insensitive examples of this kind of enzyme (e.g. cathepsin B) have been reported (see Fruton, 1960). In any case, the possibility of some specific penicillinase-liberating factor being present in these extracts cannot be excluded simply by negative results which, it might still be argued, may only reflect the difficulty of reproducing an enzymic effect which is suspected of occurring somewhere within the cell envelope, by adding the enzyme artificially from the outside. The great decrease in liberation of enzyme at a $\mathrm{pH}$ value $(5 \cdot 5)$ at which most cell enzymes might be expected to function poorly, is also consistent with the hypothesis that the phenomenon has an enzymic basis.

Although gross cell damage appears to be excluded, it can always be argued that minor degrees of damage (e.g. the initial steps of a chain of metabolic events finally leading to observable damage and lysis) are, nevertheless, an essential preliminary to exo-enzyme release. This possibility, which is really the essence of the view put forward by Nomura, Hosoda \& Yoshikawa (1958) is made less likely by the insusceptibility to the inhibitory effect of high $\mathrm{Mg}^{++}$concentration, and the absence of concomitant $\alpha$-glucosidase release which characterize 'physiological' liberation of penicillinase and thus distinguish it qualitatively from 'damage-release'.

It might, perhaps, be preferable to consider the possibility that liberation of penicillinase is a reflexion of some relatively non-specific process of change in the biochemical, chemical and physical properties of the cell envelope, affecting the extents to which several other substances, as well as penicillinase, were bound to it. Many bacterial exo-enzymes appear during the later stages of batch growth of Bacillus sp. (see Pollock, 1961 a). The reason for this is not yet understood. It is striking, for instance, to note that the period in a batch culture when penicillinase is being liberated corresponds closely to that during which $\alpha$-amylase is appearing in the medium. It would be useful, therefore, to know whether generalized changes do occur in the cell wall and other superficial cell structures over this period.

It seems clear that in Bacillus subtilis 6346 cell-bound penicillinase is normally fixed to solid cell structure, possibly in part to the cytoplasmic membrane itself. Although only a proportion $(\ngtr 50 \%)$ of this cell-bound penicillinase was conclusively shown by antiserum neutralization experiments (Kushner \& Pollock, 1961) to be on the outside of the membrane, the results as a whole are consistent with it all being there. It is possible that the membrane itself may be the site of its formation. If this be so, the mechanism of exo-enzyme release may involve detachment of enzyme from some superficial structure (which the penicillinase-releasing effect of trypsin suggests may be protein in nature, Kushner \& Pollock, 1961), followed by its passage through the cell wall. This appears, at least for the moment, to be a useful working hypothesis to guide further studies.

I would like to thank Miss Joan Fleming very sincerely for her careful and patient technical assistance. I am also grateful to Dr E. P. Abraham for gifts of cephalosporin C. 


\section{REFERENCES}

Fruton, J. S. (1960). In The Enzymes, 2nd ed., Vol. 4, Chap. 11 : Cathepsins. (P. D. Boyer, H. Lardy \& K. Myrback, eds.) New York: Academic Press.

Glauert, A. M., Brieger, E. M. \& Allen, J. M. (1961). The fine structure of vegetative cells of Bacillus subtilis. Exp. Cell Res. 22, 73.

Kushner, D. J. \& Pollock, M. R. (1961). The location of cell-bound penicillinase in Bacillus subtilis. J. gen. Microbiol. 26, 255.

McQuillen, K. (1960). In The Bacteria, Vol. 1, Chap. 6: Bacterial protoplasts. (I. C. Gunsalus \& R. Y. Stanier, eds.) New York: Academic Press Inc.

Mitcheld, P. (1961). Experimental approaches to the analysis of specific membrane transport. IUB/IUBS Symposium on Biological Structure and Function, Stockholm, 1960. (In the Press.)

Mitchell, P. \& Moyle, J. (1959). Permeability of the envelopes of Staphylococcus aureus to some salts, amino acids and non-electrolytes. J. gen. Microbiol. 20,434 .

Nomura, M. \& Hosoda, J. (1956). Nature of the primary action of the autolysin of Bacillus subtilis. J. Bact. 72, 573.

Nomura, M., Hosoda, J. \& Yoshikawa, H. (1958). Studies on amylase formation by Bacillus subtilis. The mechanism of amylase excretion and cellular structure of Bacillus subtilis. J. Biochem. (Tokyo), 45, 737.

Pollock, M. R. (1961 a). In The Bacteria, Vol. 4, Chap. 12: Exoenzymes (I.C. Gunsalus \& R. Y. Stanier, eds.). New York: Academic Press.

Pollock, M. R. (1961 $b$ ). The measurement of the liberation of penicillinase from Bacillus subtilis. J. gen. Microbiol. $26,239$.

Pollock, M. R. \& Kramer, M. (1958). Intermediates in the bio-synthesis of bacterial penicillinase. Biochem. J. 70, 665.

Richmond, M. H. (1959a). Formation of a lytic enzyme by a strain of Bacillus subtilis. Biochim. biophys. Acta, 33, 78.

Richmond, M. H. (1959b). Properties of a lytic enzyme produced by a strain of Bacillus subtilis. Biochim. biophys. Acta, 33, 92.

Salton, M. R. J. (1960). In The Bacteria, Vol. 1, Chap. 3: Surface layers of the bacterial cell. (I. C. Gunsalus \& R. Y. Stanier, eds.). New York: Academic Press Inc. 